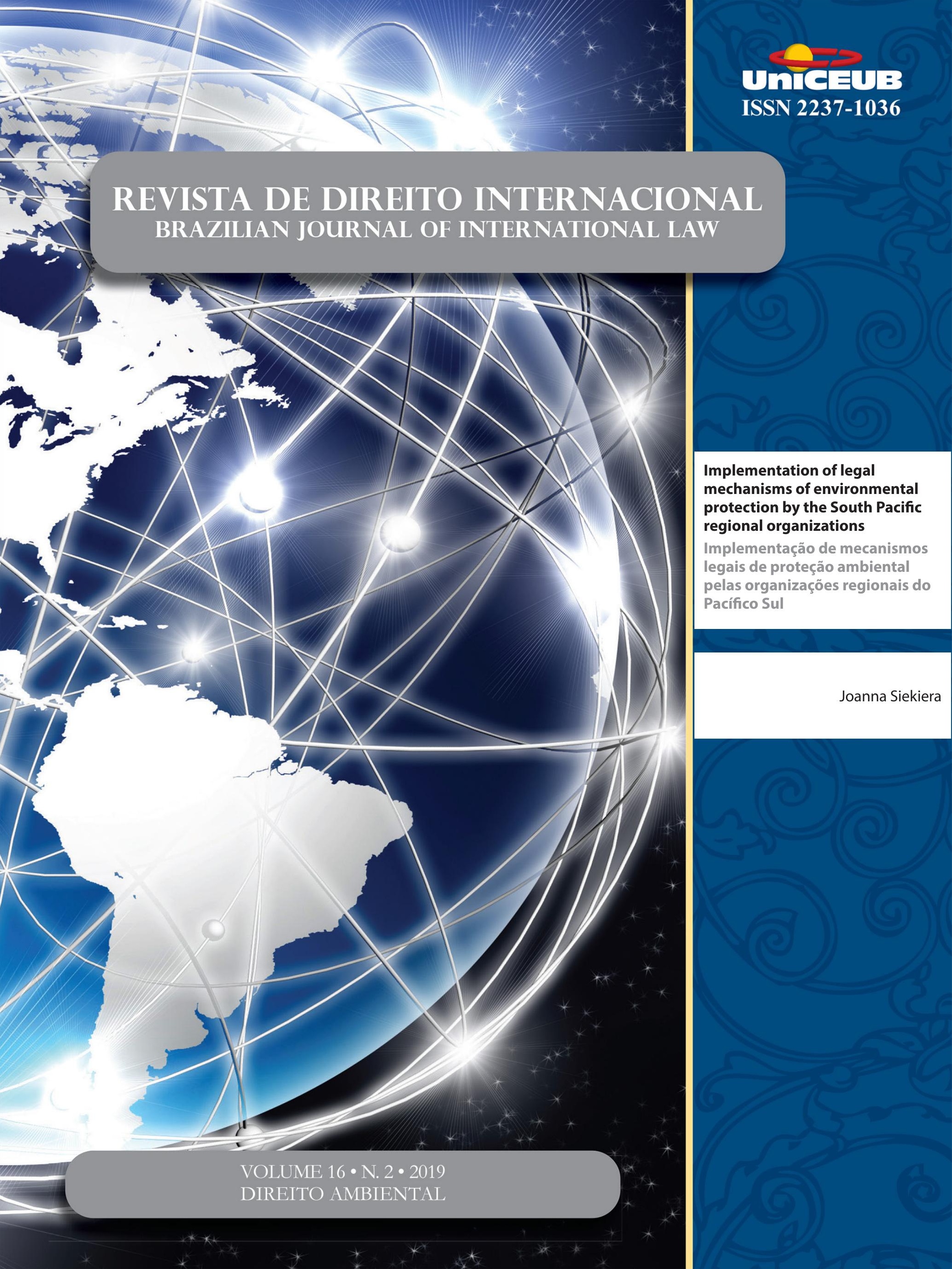




\section{Sumário}

I. Crônicas do Direito Internacional .................................................1

AMAZONIE: LE DROIT INTERNATIONAL EN VIGUEUR APPORTE DES RÉPONSES SUBSTANTIELLES ... 3 Pierre-Marie Dupuy

A eVOluÇão da SOluÇão DE CONTROVÉRSias NOS ACFIs 8 Ana Rachel Freitas da Silva

II. Dossiê Especial: Direito ambientai 14

A brief overview of Sustainable DeVelopment: HOW A DEBATEd CONCEPT With A MUCH-CONTESTED LEGAL NATURE COULD PERFORM A VALUABLE ROLE IN THE DECISION-MAKING ......16 Natali Francine Cinelli Moreira

A meta 11 de Aichi e as Áreas marinhas protegidas em grande ESCALA: proteção ambienTAL OU OPORTUNISMO POLÍTICO?

Alexandre Pereira da Silva

LITIGÂNCIA CLIMÁTICA COMO ESTRATÉGIA JURISDICIONAL AO AQUECIMENTO GLOBAL ANTROPOGÊNICO E MUDANÇAS CLIMÁTICAS

Délton Winter de Carvalho e Kelly de Souza Barbosa

AsSESSMENT AND CHALlENGES OF CARBON MARKETS

Louise Pigeolet e Arnaud Van Waeyenberge

As abordagens dos países da América Latina e Caribe sobre a mobilidade humana proVOCADA PELAS MUDANÇAS CLIMÁTICAS

Diogo Andreola Serraglio e Heline Sivini Ferreira

Implementation of Legal mechanisms of environmental protection by the South PaCIFIC REGIONAL ORGANIZATIONS 116 Joanna Siekiera 
CONCILIATING THE OVERLAP OF PROTECTED AREAS AND TRADITIONAL TERRITORIES: LEGAL INNOVATIONS FOR BIOLOGICAL DIVERSITY CONSERVATION IN BRAZILIAN PARKS

Nathalia Fernandes Lima e Solange Teles Silva

O USO DE DRONES COMO INSTRUMENTO PARA A CONSERVAÇÃo DA BIODIVERSIDADE NO BRASIL141 Larissa Suassuna Carvalho Barros e Marcia Dieguez Leuzinger

Agrotóxicos e direitos humanos no contexto global: o Brasil EM Risco de Retrocesso?

Marcelo Pretto Mosmann, Letícia Albuquerque e Isabele Bruna Barbieri

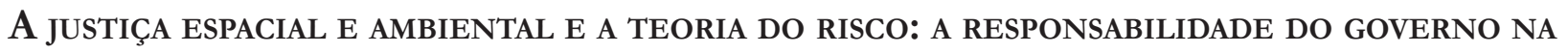
PREVENÇÃo CONTRA DESASTRES (NO BRASIL). 169

José Adércio Leite Sampaio e Edson Rodrigues de Oliveira

The judgment of the case Xucuru People v. Brazil: Inter-American Court of Human RigHTS BETWEEN CONSOLIDATION AND SETBACKS

Gabriela Cristina Braga Navarro

II. Artigos sobre outros temas

NACIONALIDADE: NOVAS REGRAS, VELHOS PROBLEMAS

226

Paulo Henrique Faria Nunes

O EXERCíCIO DA JURISDIÇÃO INTERAMERICANA DE DIREITOS HUMANOS: LEGITIMIDADE, PROBLEMAS E POSSÍVEIS SOLUÇÕES

Felipe Grizotto Ferreira, Guilherme Perez Cabrale Lucas Catib de Laurentiis

A proteção da identidade de gênero na jurisprudênCia da Corte Europeia de Direitos Humanos

Gabriel Coutinho Galil

O COMITÊ JURÍdico INTERAMERICANO dA OEA E A CODIFICAÇÃo DO DIREITO INTERNACIONAL REGIONAL. 
O caso Petruhhin e o princípio do nível mais elevado de proteção no tocante aos diREITOS FUNDAMENTAIS NO ÂMBITO DA UNIÃo EUROPEIA............................................304

Clovis Demarchi e Jaine Cristina Suzin

A AUTONOMia da VONTADE NA ESCOLHA dA LEI APLICÁVEl AOS CONTRATOS DE COMÉRCiO INTER-

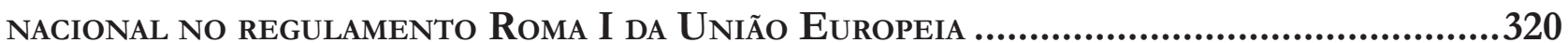

Aline Beltrame de Moura e Rafaela Hörmann

A JuRisdição da ICANN: desafios atuais e Prospectivas futuras...............................335 Aziz Tuffi Saliba e Amael Notini Moreira Bahia

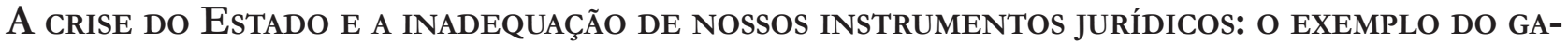
RANTISMO PENAL NO BRASIL.

Oswaldo Poll Costa e Francisco Quintanilha Veras Neto

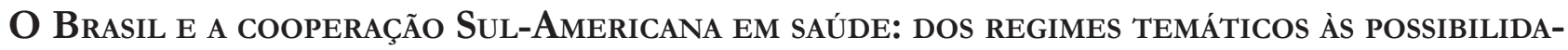
DES DE EFETIVAÇÃo ESTRUTURANTE

Ademar Pozzatti Junior e Luiza Witzel Farias

III. RESENHAS

Resenha da obra: SILVA, Waldimeiry Correa da. Regime internacional de enfrentaMENTO AO TRÁFICO DE PESSOAS: AVANÇOS E DESAFIOS PARA A PROTEÇÃo DOS DIREITOS HUMANOS. Rio de Janeiro: Lumen Juris, 2018. 385

Mércia Cardoso de Souza e Guirino Nhatave 


\title{
Implementation of legal mechanisms of environmental protection by the South Pacific regional organizations*
}

\author{
Implementação de mecanismos legais de \\ proteção ambiental pelas organizações \\ regionais do Pacífico Sul
}

Joanna Siekiera**

\begin{abstract}
Objective of the article is to present a multitude of the South Pacific regional organizations, whose one of the most vital issue is to implement legal mechanisms of environmental protection. As the Pacific countries and territories are the most affected by the climate change effects, the goal of the politicians, diplomats, representatives of private sector and civil society organizations is to protect their islands. The islanders have been trying to achieve that through multilateral gathering, seminars and other so-called soft law instruments, but also, recently, through hard law mechanism, which can be de iure executed. There are however many obstacles which come from both structural and social barriers of the South Pacific nations. The methodology, which has been used to write this article, is the legal analysis of the documents made on both national and transnational lever, mainly by the regional intergovernmental organizations, as well as non-binding communiqués after summits and further political declarations. The value author wishes to bring is first of all publicising the Pacific region, as it is not anymore isolated or dependent on the bigger global actors. Secondly, environmental protection made by the grass roots initiatives, being de facto the regional organizations, can shed new light on this matter. Conclusion shall, nonetheless, present still a long way before the South Pacific microstates on their way to achieving both better regional cooperation, as well as mechanisms of more effective implementation of the regional norms.
\end{abstract}

Key words: implementation of norms, legal mechanisms, environmental protection, South Pacific, Pacific, regional organizations

\section{Resumo}

* Recebido em 17/08/2019

Aprovado em 29/10/2019

** International lawyer at the Univeristy of Bergen, Norway; PhD at the Warsaw School of Economics, Poland; PhD scholar at the Victoria Univeristy of Wellington, New Zealand. Email: joanna.axe@gmail.com
O objetivo do artigo é apresentar uma multidão de organizações regionais do Pacífico Sul, cuja questão mais vital é a implementação de mecanismos legais de proteção ambiental. Como os países e territórios do Pacífico são os mais afetados pelos efeitos das mudanças climáticas, o objetivo dos políticos, diplomatas, representantes do setor privado e das organizações da sociedade civil é proteger suas ilhas. Os ilhéus têm tentado conseguir isso por meio 
de reuniões multilaterais, seminários e outros instrumentos chamados soft law, mas também, recentemente, por meio de mecanismos de hard law, que podem ser executados. No entanto, existem muitos obstáculos que surgem das barreiras estruturais e sociais das nações do Pacífico Sul. A metodologia utilizada para redigir este artigo é a análise jurídica dos documentos elaborados com alavanca nacional e transnacional, principalmente pelas organizações intergovernamentais regionais, bem como comunicados não vinculativos após cúpulas e declarações políticas adicionais. O valor que o autor deseja trazer é antes de tudo divulgar a região do Pacífico, pois não está mais isolada ou dependente dos maiores atores globais. Em segundo lugar, a proteção ambiental feita pelas iniciativas de base, sendo de fato as organizações regionais, pode lançar uma nova luz sobre esse assunto. No entanto, a conclusão ainda apresentará um longo caminho até que os microestados do Pacífico Sul estejam no caminho de alcançar uma melhor cooperação regional, bem como mecanismos de implementação mais eficaz das normas regionais.

Palavras-chave: implementação de normas, mecanismos legais, proteção ambiental, Pacífico Sul, Pacífico, organizações regionais

\section{Introduction}

The Pacific region has long been neglected by the global actors and scientists due to many reasons. The motives of leaving the Pacific basin aside were varied, firstly because of the long geographic distance, logistical problems to get to the islands, but most importantly, because of the poor conditions of undeveloped postcolonial countries, totally dependent on their metropolis. After two bursts of decolonisation of the South Pacific (namely 1962-1970 and 1974-1980), microstates from the subregions of Micronesia, Polynesia and Melanesia began to develop their own nationhood. They started to gain more and more importance in geopolitics, but also in the scientific area. Also, what needs to emphasis at the beginning of this article, is the fact that both western politicians and scientists do not call the Pacific as the region of future for no reason. Even the name was forged for the times we live in: the $21^{\text {st }}$ century is called as "the Pacific century". It all comes from the fact of

\footnotetext{
See: CLINTON Hilary, America's Pacific Century, "Foreign Policy",
}

the huge geographical, cultural and political specificity of the Pacific entities. Here, the legal and economical aspects cannot be left unsaid. The eventually independent governments of the Pacific countries were de facto and de iure able to build own legal systems along with the free markets.

Similarly, the Pacific basin is the most complex region through out the world. In the close neighbourhood, there are varied international law entities. The subjective analysis of implementation of environmental protection legal mechanisms by the South Pacific regional organizations shall be closed up to the following countries: 1. sovereign states: Australia, Fiji, Kiribati, Nauru, New Zealand, Papua New Guinea (PNG), Samoa, Tonga, Tuvalu, Vanuatu, the Solomon Islands; 2. free associated states: Niue and the Cook Islands (with New Zealand), the Federated States of Micronesia (FSM), Palau and the Marshall Islands (with the United States); 3. dependent territories of other larger and more influential states. Here such legal diversification is indeed needed to present. It comes from the fact that not every country in the Pacific can be treated as a state, due to the Montevideo Convention from 19332. Therefore, not every party of regionalisation, willing to act for the sack of environmental legal changes, can de iure act independently. Also, International organizations law, which is based on the Vienna Convention on the Law of Treaties from $1969^{3}$, says clearly that only states can be a full (meaning acting with unlimited international legal personality, exercising all rights and duties on the international arena) member of an intergovernmental organization (IGO), which in turn has to be based on an international agreement ${ }^{4}$.

That being said, the very useful term when dealing with the members of the Pacific regionalism is "the $\mathrm{Pa}$ cific countries and territories" (PICT). As the free-associated states (FAS) are not fully independent states, but

11.11.2011; SCOTT David, The 21st Century as Whose Century?, "Official Journal of the Political Economy of the World-System Section of the American Sociological Association”, 2007/XIII(2); TERRY Sarah, Where the wave of the future will crest?, "The Christian Science Monitor", 28.09.1982.

2 Montevideo Convention on the Rights and Duties of States from 26 December 1933, art. 1 enumerated the conditions to be fulfilled by an entity to become a state. However, after that the international recognition is also required.

3 Vienna Convention on the Law of Treaties from 22 May 1969.

4 Vienna Convention on the Law of Treaties from 22 May 1969, art. 2, paragraph 1 , letter a. 
theirs external policy is being held by the partner state ${ }^{5}$, the whole process of engaging of FSA in the regional climate change initiatives is de iure limited. As the Pacific region already possesses its significant influence on development of various branches of science, including the climate change discussion, the questions of the Oceania regionalism and/or regionalisation ${ }^{6}$, the South Pacific cooperation and establishing of regional relations, mainly through the regional IGO, are not enough touched upon in the Euroatlantic zone, including the South America. Those issues thus require further analysis and certainly need to be explored also in the Brazilian literature.

Finally, a few words on the methodology used when writing this article have to be given. As this is strictly legal analysis, the research process was based on non-reactive researches. These studies take into account the method of analysing the content of the literature on the subject (mainly in English, but also in Polish) and legal regulations (international, regional and internal law in the original English). Then, the method of analysing official data (including international organization bodies) was used in order to examine existing strategic and program documents. The secondary source of data included statistical compendia of IGO, as well as the analyses of the level of development and the rule of law prepared by the non-governmental organizations (NGO). Finally, it was necessary to trace the heritage of the UN, the same as selectively chosen treaties establishing regional organizations. This fragment of the work has a Comparative law dimension.

\section{South Pacific regionalisation}

As PICT are the most affected by the climate change effects, the common goal of the politicians, diplomats, representatives of private sector and civil society orga-

\footnotetext{
5 Just compare the American agreements, called COFA: Compact of Free Association Agreement between the United States of America and the Marshall Islands Treaties and other International Acts (Series 04-501) from 30 April 2003 (amended version of the initial 1986 agreement), Compact of Free Association Agreement between the United States of America and the Micronesia Treaties and other International Acts (Series 04-625) from 14 May 2003 (amended after 1986); Compact of Free Association between the Government of the United States of America and the Government of Palau (48 USC 1931 note; Public Law 99-658) from 1 October 1994.

6 Those terms will be clarified in the next part of the article.
}

nizations (CSO) is to protect their islands. The islanders have been trying to achieve that through multilateral gathering, seminars and other so-called soft law instruments, but also, recently, through hard law mechanism, which can be de iure executed. There are however many obstacles which come from both structural and social barriers of the South Pacific nations. To understand better such regional phenomenon in the South Pacific one needs to realise the characteristic of the region in its legal frameworks.

After the extended and complex process of decolonisation, and then launching own, sovereignly driven governments and microeconomies, PICT were able to establish their national, regional and global politics. For the purpose of this article, the most interesting is the second stage of cooperation - at the regional le$\mathrm{vel}^{7}$. The $80 \mathrm{~s}$ of the $20^{\text {th }}$ century have brought many social and political changes to the nations of the South Pacific. This period is also called as the breaking point of regionalisation worldwide. Regionalisation started to be seen as an alternative, a response on ineffective and very often unfair and devastating process of globalisation for the smaller and less developed countries. The widespread membership in regional institutions, regional trade agreements (RTA) brought a new phenomenon in both international law and political science - regionalism. It can be understood as political and economic values, ideas and objectives, which contribute to establish and provide a creation of a particular region. Very often such formal policy leads to institution building, exactly through the regional organizations $^{8}$. All difficulties in reaching agreements through multilateral trade negotiations, between so varied states struggling with different civilisation problems had led to development of local programs. The most obvious example tends to be the European Union (EU). Here we could have observed the phenomenon of regionalisation - "the process of region formation by which regions come into existence and are consolidated"”.

Other regions, after becoming aware of own local

As a region exists between the state and the global level.

BADIE Bertrand, BERG-SCHLOSSER Dirk, MORLINO Leonardo (ed.), International Encyclopedia of Political Science, vol. 2, Los Angeles: SAGE, 2011. p. 2238-2248; HAFEZ Zakir, The Dimensions of Regional Trade Integration in Southeast Asia, Ardsley: Transnational Publishers, 2004. p. 5

9 BADIE Bertrand, BERG-SCHLOSSER Dirk, MORLINO Leonardo (ed.), International Encyclopedia of Political Science, vol. 2, Los Angeles: SAGE, 2011. p. 2238-2248. 
identity and thus more effective and quicker way of reaching compromise locally than on the global level, started to develop their regional cooperation mechanism, through regionalisation. Then, there was an evident expansion of other regional projects. The examples of these state-led regional frameworks are now the Association of Southeast Asian Nations (ASEAN), the African Union (AU), the North American Free Trade Agreement (NAFTA), and the Southern Common Market (MERCOSUR ${ }^{10}$ ). ${ }^{11}$ Regionalisation and regionalism became important phenomena in International law. Hence, one can assume regionalisation as regional cooperation de facto, with long-term intensification and deepening of relations through the economic, social, cultural and political linkages. While regionalism is perceived as regional cooperation de iure, through the institutions building, and eventually creating common norms, which do harmonize the whole region. ${ }^{12}$ Such neighbourly integration can be observed in many exchange mechanisms and free market instruments, such as free trade zone, customs union, common market, monetary union, or even political union-federation.

The South Pacific regionalism is very complex, as it additionally comprise of three subregions, varied in culture, languages and attachment to own history, mainly colonial, but also legal orders, which are very often perceived as "imposed law"13 after the European invaders. According to the author's calculation, there are over 30 regional organizations, status of which sometimes is hard to find. Either it is an IGO or a NGO, it will further affect creation of the possible legal norms for their member states ${ }^{14}$. Likewise, there are a dozen or so in-

10 Spanish: Mercado Común del Sur.

11 BORKOWSKI Paweł Janusz, Polityczne teorie integracji miedsynarodowej (Political Theories of International Integration), Warsaw: Difin, 2007. p. 190; KLABBERS Jan, An Introduction to International Law, Cambridge: Cambridge University Press, 2011. p. 29; SUŁEK Mirosław, SYMONIDES Janusz (ed.), Państwo w teoriach i praktyce stosunkón miedsynarodowych (The State in the Theories and Practice of International Relations), Warsaw: Wydawnictwo Uniwersytetu Warszawskiego, 2009. p. 297.

12 ORŁOWSKA Renata, ŻOŁA_DKIEWICZ Krystyna, Globalizacja i regionalizacja w gospodarcze światowej (Globalisation and regionalisation in the world economy), Warsaw: Polskie Wydawnictwo Ekonomiczne, 2012. p. 169-171.

13 HUGHES Bob, Report on the South Pacific countries "New Zealand Yearbook of International Law" 2005/2. p. 274.

14 It has to be marked that not only a state can become a member of an organization. As the 21 st century is a unique time when socalled "non-states actors" (NSA) become more and more influential, they do participate in creating and functioning of global and regional organizations. Simultaneously, the informal character of many ad formal regional forums at the South Pacific Ocean territory. What seems to be essential here is the fact that the Pacific organizations quite often change their names. It is mainly due to expanding the scope of their territorial activity, and thus also membership. Here it is worth giving some examples: the Pacific Regional Environment Programme was previously called the South Pacific Regional Environment Programme, while the Secretariat of the South Pacific (SPC) was officially renamed as the Pacific Community. However, due to being the longest functioning Pacific IGO, SPC is still recognised under its old name. Additionally, some other regional bodies have been incorporated by largest or newest institutions. It was the case with the South Pacific Board of Educational Assessment, which was incorporated by the previously mentioned SPC. Finally, some organizations create further, specialised smaller institutions, just like it was with the Pacific Islands Forum Fisheries Agency (FFA) established by the Pacific Islands Forum (PIF). Consequently, we can observe a so-called "spaghetti effect", where singular states are parties to some regional treaties or agreements establishing regional organizations, and/or members of numerous formal organizations and/or informal gatherings, whose activities become less effective or simply blur at the end.

\section{Implementation of norms by the Pacific states}

Implementation of norms, created both at the national level, through the regional IGO and arrangements, or agreed at the global, mostly the UN level, does not go smoothly in the South Pacific. We have to bear in mind the constant and deeply rooted struggles, which PICT share with the newly adopted terms of democracy, transparency, accountability, human rights and equality. Those notions are in fact not known in the autochthons' island heritage, which is strongly related to the hierarchical tribal society ${ }^{15}$. Implementation of

hoc types of regional networks, their characteristic pluralism and multidimensionality give rise to a variety of new entities participating in the whole process of regionalisation too.

5 MOALA Kalafi, Why Pacific reformers find it difficult (21.07.2015). Available at: <http://pacificpolicy.org/2015/07/why-pacific-reformers-find-it-difficult> Assess on: 15.08.2019; TAUMOEFOLAU Melenaite, Why Tongan has no word for human rights (8.04.2019). Available at: <https://www.newsroom.co.nz/@ideasroom/2019/04/08/521574/when-are-human-rights-a-right-for-to 
newly ordered laws of any legal mechanisms is being disturbed by the social features. Those features have both formal and merit nature. In the overwhelming majority of the Pacific islands, there can be observed two key issues: 1 . inefficiency of the state administration bodies carrying out reforms, and 2: parliamentary structures with no real effect. First problem appears already at the stage of implementing reforms into the legal orders. PICT, as the former colonies, did not establish any legal colleges or administrative "breeding grounds for human resources", who could build independent state apparatus. Pacific politicians, coming from local tribes or clans, did not have any vocal education (not mentioning tertiary one) to introduce the standards necessary to perform reforms in postcolonial states ${ }^{16}$. In addition, the procedural reconstruction of the former colony's state system required establishment of an appropriate public body. Yet, the only equivalent in the Pacific appeared to be the governor institution - introduced however by the metropolis themselves, staffed with the European officials. Hence, PICT were forced to take over (adopt) the legal orders after their former administrators. Such way of transition of any process, especially legal transformation, could not, and still do not, reach social acceptance $^{17}$.

Regarding the mentioned fact that the national $\mathrm{Pa}-$ cific parliamentary structures have no real effect on law making, it should be stated that this is due to both insufficient training (or its complete absence) of public officials, as well as the lack of adequate competence of particular legal organs and institutions, including enforcement of established principles. Indeed, when the law cannot be exercised, it becomes a dead letter. Some countries are in fact aware of these structural problems. They have created separate offices aimed at controlling implementation of reforms. For example, a special commission in Fiji deals with the legal and political eva-

nga?fbclid=IwAR2itIEjda1 KpTwmhZSOt2YHBIzIedH-hMMA8HNxP0HIJtofzfVCdFL61M0\#> Assess on: 15.08.2019.

${ }_{16}$ Of course, that situation has been changing, as the previously there was the only Faculty of Law at the Univeristy of South Pacific, based in Vanuatu. Nonetheless, students are being sent to the closest faculties in New Zealand and Australia, what requires capital and time. This phenomenon of such education tourism within the South Pacific could be observed by the author during her staying at the Victoria Univeristy of Wellington.

17 VAN TREASE Howard, The Politics of Land in Vanuatu: From Colony to Independence, Suva: Institute of Pacific Studies of the University of the South Pacific, 1987; HUGHES Bob, Report on the South Pacific countries "New Zealand Yearbook of International Law" 2005/2. luation of the effectiveness of changes. It watches over the correctness of merging two legal orders - local and postcolonial $^{18}$.

Finally, the obstacles in full and effective implementation of legal norms on both national and regional level have the social and cultural base. First of all, it is because of the bureaucracy - adamant, rigid, detached from any local realities. Secondly, features of the society of traditionalists and their static culture are strongly noticeable in any attempt to change the status quo. Indeed islanders, both average citizens, as well as officials or politicians, effectively oppose the introduction of any changes that, in their opinion, could further worsen the status quo of public administration. Thirdly, but no less importantly, some researches mention the impact of institutionalized religion, along with its misinterpretation, instead of experiencing authentic faith by a significant rate of the Pacific population ${ }^{19}$.

\section{Legal mechanisms of environmental protection}

Unfortunately, from the legal point of view, the imperfect democracies from the South Pacific create imperfect regional bodies and institutions. The same obstacles, formal and merit problems in forming, implementing and executing norms are being transferred from the national level onto the regional, and then global one. We tend to forget that politicians, officials and representatives of various private and public sector branches are only humans, coming and brought by the same society, as the rest of the citizens.

Environmental protection, next to the tuna fishery,

18 Fijian Law Reform Commission, a special public agency that oversees reforms, as well as their effectiveness and impact on society, operates under the Fiji Law Reform Commission Act from 6 April 6 1979, which had two amendments in 1986 and the latest in 2016. Office of the Attorney General. Available at: <https://laws. gov.fj/Acts/DisplayAct/2295\#> Assess on: 15.08.2019.

19 ALLERFELDT Kristofer, Race, Radicalism, Religion, and Restriction: Immigration in the Pacific Northwest 1890-1924, London: Greenwood Publishing Group, 2003. p. 33; HERDA Phyllis, REILLY Michael, HILLIARD David, Vision and Reality in Pacific Religion: Essays in Honour of Niel Gunson, Canberra: University of Canterbury, 2005. p. 346; MOALA Kalafi, Why Pacific reformers find it difficult (21.07.2015). Available at: <http://pacificpolicy.org/2015/07/why-pacific-reformers-find-it-difficult> Assess on: 15.08.2019; LANGA'OI Palenitina, The Roots of Instability: Administrative and Political Reform in Tonga, „Ritsumeikan Journal of Asia Pacific Studies” 25/2009. p.21-35. 
tourism, and economic exchanges, takes one of the most important places at the regional gatherings' agenda. Not surprisingly, climate change along with its disastrous effects on the Pacific islands appears to be another key factor, which is able to bring the head of states from Melanesia, Micronesia and Polynesia together - to the same table as equally treated parties. The differences, which are noticeable on the daily basis cooperation (mainly in the aspects of humanitarian, social and economical development, foreign investments ratios and openness on interactions with the Pacific Rim global players) suddenly become less visible when it comes to the joint problem of the ocean raising. The predicted lose of most or all of the land of especially Kiribati, the Marshall Islands, Tuvalu and Tokelau by the late $21^{\text {st }}$ century ${ }^{20}$ is the most effective factor to launch and maintain proper regionalism ever.

As global climate change is affecting already not only the sea level rise, but also is responsible for flooding, droughts and recurrent extreme weather, being painfully visible especially in the Pacific Ring or Fire ${ }^{21}$. All of this will make coastal areas (literally almost 100\% of the PICT territories) gradually uninhabitable, leading to submersion of urban centres, migrations of displaced people, becoming now called as "ecological refugees"22, and finally economic and political upheaval ${ }^{23}$. The previously presented the Pacific regional specificity, will,

20 According to United Nations High Commissioner for Refugees (UNHCR) 2009. Climate Change and Statelessness: an Overview. Submitted to the UNFCCC 15 June 2009; BECKER Melanie, MEYSSIGNAC Benoit, LETRETREL Camille, LLOVEL William, CAZENAVE Anny, DELCROIX Thierry, Sea level variations at tropical Pacific islands since 1950, "Global \& Planetary Change" 2012/80-81. p. $80-81,85-98$.

${ }_{21}$ This phenomenon overlaps the Pacific Rim itself. The Pacific Ring of Fire is an area where there have been occurred a great number of fatal natural disasters, mostly earthquakes, volcanic eruptions, tsunamis and cyclones. More on this: RINARD HINGA Bethany, Ring of Fire: An Encyclopedia of the Pacific Rim's Earthquakes, Tsunamis, and Volcanoes, Santa Barbara: ABC-CLIO, 2015.

22 Until now, however, there is no legal definition of this group of asylum seekers under International law. BLACK Richard, Environmental refugees: myth or reality?, University of Sussex, Working Paper No. 34, March 2001. p.1. The definition suggested by the Organisation for Economic Co-operation and Development (OECD): is such: "An environmental refugee is a person displaced owing to environmental causes, notably land loss and degradation, and natural disaster." Assess on: <https://stats.oecd.org/glossary/detail. asp?ID=839> Available at: 15.08.2019.

23 NICHOLLS Robert J. and CAZENAVE Anny, Sea-Level Rise and Its Impact on Coastal Zones, "Science" 2010/328(18). p. 1517-1520; VIDAS Davor, The Anthropocene and the international law of the sea, "Philosophical Transactions of the Royal Society", 2011/369. p. 909-925. and already do, attain global relevance, first for other island states, then for the coastal regions of the world at large.

Multitude and complexity of the climate change problem indeed bring closer the largest and most influential Pacific IGO (SPC, Pacific Islands Forum, PIF and the newest platform - the Pacific Islands Development Forum, PIDF). The Pacific response to the global lack of activity (in the legal context being lack of implementation of any legal norms and mechanisms of environmental protection) was expressed significantly in 2015. Before analysing those two declaration signed in September 2015, here is worth mentioning the down root initiative of the Pacific island developing stated (PIDS), which made attention globally. PSIDS are an unofficial structure within the UN, which are trying to improve their tragic situation and finally speak the common voice on the international arena, previously being unheard as single islands. It is PSIDS who successfully introduced and popularize the term of "blue economy", as a contrast, or rather a supplement, to well-known and widely promoted "green economy" (developing sustainable sources of energy and reducing environmental risks for the climate). Therefore by creating a simple notion, not even a legal definition, the Pacific governments have given a clear signal of their unity when it comes to their separate problems coming from the strictly maritime environment ${ }^{24}$.

The adoption in 2015 two soft law instruments by the regional IGO can be seen as an important step towards environmental protection in the South Pacific. PIF issued its Declaration on Climate Change Action on 10 September $2015^{25}$, while PIDF signed its own Declaration on Climate Change a few days earlier, on 4 September $2015^{26}$. Both Forums do consider themselves as the key political and economic regional organization, being responsible for harmonization the local politics and holding legal reforms. Both of them have in their agendas climate protection as one of the most vital issues to work on. Unsurprisingly, PIF and PIDF were willing to present their own version of a regional document in advance of the annual UN Conference

\footnotetext{
24 CLAUDIO Cora, From green to blue economy, "Philippine Daily Inquirer" (23.06.2013).

25 Pacific Islands Forum Leaders Declaration on Climate Change Action from 10 September 2015.

26 Pacific Islands Development Forum Suva Declaration on Climate Change from 4 September 2015.
} 
of Parties (COP $)^{27}$, which took place on 7- 8 December 2015 in Paris. Both declarations, being however not hard law agreements and therefore not legally binding international treats, but "only" political declaration of a good will, emphasising the pressing need for transition of energy from fossil fuels to renewable energy, as well as other blue-green technologies. The common denominator was likewise a call for establishment of the new legal instrument during the $21^{\text {st }} \mathrm{COP}$, being in turn equipped with the executive mechanisms, to reverse global warming. The Paris Agreement ${ }^{28}$, despite its ambitious norms, has not changes anything either. The lack of implementation, its eventual partiality or even intentional neglect of many universal agreements by the larger signatories does present a sad and hopeless feedback for PSIDS. If the Pacific states cannot relay on the more developed states in their joint legal and political fight for the climate change, they become left alone.

Implementation of legal mechanisms of international environmental protection agreements is as complex as the whole Public International Law execution. Nonetheless, the Pacific, being so specific and unique, suffers from both ineffective systems - universal and regional. Regional mechanisms are mainly soft law mechanists, achieved through traditionally accepted gatherings of politicians, social activists and ecological NGO. The results of those forums, conferences or summits are only declarations, communiqués, statements for the future, where the signatories only ineffectively "call for". Those tools do not possess, as they cannot possess, any legal binding for the signatures. They could, though, become legally valid norms, if only PICT decided to incorporate those declarations to own national legal orders at the first place, and then to execute their national norms at the regional level. In other words, the simples and most effective method, at least in theory, appears to be codification of the environmental protection norms. Any articles of regional declarations, agreements, treaties should be therefore equipped in legal force, and after

\footnotetext{
${ }^{27}$ Conference of the Parties is a governing body of the United Nations Framework Convention on Climate Change (UNFCCC), the international environmental treaty adopted by the United $\mathrm{Na}$ tions Conference on Environment and Development (UNCED) on 4 June 1992.

28 Paris Agreement under the United Nations Framework Convention on Climate Change was signed on 22 April 2016 and entered into force on 4 November 2016. Its effectiveness along with the lack of binding enforcement mechanism will not be analysed here, though.
}

that, any state, organization or citizen could invoke the rights and duties derived from those norms.

However in practise, as it was presented in the beginning of this article, PICT struggle with many substantial obstacles in their legal orders, what prevent them from full and effective implementation of any regional arrangements. Not to become over pessimistic though, it should be stated a few suggestions to improve the current state of fact. The new institutional-merit changes need to be executed, but constantly stressing the $\mathrm{Pa}$ cific heritage of the strong linkage between the Mother land and her children. Such terminology, deeply embedded in the autochthonous culture of the islanders can make them feel important and help understanding that the legal changes are not being made against them, but in order to protect their beloved maritime nature. The competence-importance competition between the largest IGO in the Pacific has speeded up the process of regionalism, but also its level of representing the members on the broader scene, including the UN. By issuing newest declarations and communiqués ${ }^{29}$, suddenly the world has noticed huge determination of the previously unheard microstates.

\section{Final conclusions}

Regionalism in the South Pacific takes place mainly through multilateral agreements. Multilateral agreements, on the other hand, usually take the form of acts constituting international intergovernmental organizations, through which states implement their regional policy, also environmental policy. It should be noted here that the regional IGO were not created solely to carry out their integration functions. It cannot be forgotten that they are a "derivative material" from the relatively newly created entities - states. Those postcolonial,

\footnotetext{
29 Only to mentioned a few which headline the urgent need of the environmental protection changes: Framework for Pacific Regionalism Pacific Islands Forum Leaders, July 2014; Pacific Islands Forum Secretariat Pacific Plan for Strengthening Regional Cooperation and Integration, November 2007; Pacific Community Strategic Plan 2016-2020, Sustainable Pacific development through science, knowledge and innovation (2015); Explanatory Notes on the PIDF Charter from the PIDF3 Leaders' Summit 2-4 September 2015; Third PIDF Leaders Summit, Building Climate Resilient Green Blue Pacific Economies, 2-4 September 2015; Polynesian P.A.C.T. (Polynesia Against Climate Change) Taputapuatea Declaration on Climate Change, Polynesian Leaders Group from 16 July 2015.
} 
finally sovereign states thereby wanted to emphasize their international legal personality, which is realized, among others, by maintaining diplomatic relations and establishing other entities, just like organizations. This is where the second, unofficial reason for establishment the regional groupings by PICT comes from. This allows their members to create and conserve international identity ${ }^{30}$. Thanks to such continuity and effectiveness of their activities on the international arena, the newly formed PICT classify themselves as active players having a real impact on the form of international relations, at the same time underlining the importance of environmental protection.

There can be suggested a few methods of improving implementation of legal mechanisms in the South Pacific by the main drivers of regionalism, that is by IGO: 1. Creation of non-binding forums for discussion of expert and advisory groups, which would consist of scientists, businessmen and NGO activists who, thanks to their daily practice, could express opinions on key issues for their governments, so often lacking the experts; 2. Underlining respect for the principle of sovereignty during the competence transfer to supranational bodies, in order to emphasize independence of the regionalism parties, so fragile on any colonialism features; 3. Shaping complementarity in economic relations between variously prospering Pacific countries, as well as the equal division of labour in joint institutions; 4) Need for the regionally binding norms, being executed in every Pacific state. Another aspect is the spaghetti effect of misrepresentation of the Pacific IGO, NGO, and other subregional initiatives, like transnational bodies and declarations ${ }^{31}$.

Overall, it does appear that implementation of legal mechanisms of environmental protection by the South Pacific regional organizations is as weak as globally. However, the Pacific small island stated rely fully

\footnotetext{
30 FRY Greg, TARTE Sandra, The New Pacific Diplomacy, Canberra: Anu Press, 2015. p. 468.

31 The latest example is another failure to reach an agreement on climate change among PICT during the PIF summit held in Tuvalu, on 14.08.2019. LYONS Kate, Australia waters down Pacific Islands plea on climate crisis (15.08.2015), Assess on: <https://www.theguardian. com/world/2019/aug/15/australia-waters-down-pacific-islandsplea-on-climate-crisis> Available at: 16.08.2019; CLARKE Melisa, Pacific leaders, Australia agree to disagree about action on climate change (16.08.2019), Assess on: <https://www.abc.net.au/news/2019-0815/no-endorsements-come-out-of-tuvalu-declaration/11419342> Available at: 16.08.2019
}

on their maritime environment, while any of their numerous internal struggles, postcolonial problems and structural legal obstacles cannot prevent them from the effective and successful reforms. Newly independent, developing own meaning of imposed democracy, they are not able to force implementation of any kind of norms by themselves. They do need role models, advisers and supporters in maintaining the global initiative, which is now combating the climate change effects. Nonetheless, unity indeed makes strength, so the joint activities, through both soft and hard law methods, can lead the Pacific island governments to achieve their common goal. In the most possible globalised worlds, they just cannot be left alone.

\section{References}

ALLERFELDT Kristofer, Race, Radicalism, Religion, and Restriction: Immigration in the Pacific Northwest 1890-1924, London: Greenwood Publishing Group, 2003. p. 33.

BADIE Bertrand, BERG-SCHLOSSER Dirk, MORLINO Leonardo (ed.), International Encyclopedia of Political Science, vol. 2, Los Angeles: SAGE, 2011. p. 2238-2248.

BECKER Melanie, MEYSSIGNAC Benoît, LETRETREL Camille, LLOVEL William, CAZENAVE Anny, DELCROIX Thierry, Sea level variations at tropical Pacific islands since 1950, "Global \& Planetary Change" 2012/80-81. p. 80-81, 85-98.

CLARKE Melisa, Pacific leaders, Australia agree to disagree about action on climate change (16.08.2019), Assess on: <https://www.abc.net.au/news/2019-08$15 /$ no-endorsements-come-out-of-tuvalu-declaration/11419342> Available at: 16.08.2019

BLACK Richard, Environmental refugees: myth or reality?, University of Sussex, Working Paper No. 34, March 2001. p.1

BORKOWSKI Paweł Janusz, Polityczne teorie integracji mięsynarodowej (Political Theories of International Integration), Warsaw: Difin, 2007. p. 190.

CLINTON Hilary, America's Pacific Century, "Foreign Policy", 11.11.2011.

Compact of Free Association Agreement between the United States of America and the Marshall Islands Treaties and other International Acts (Series 04-501) from 
30 April 2003. Compact of Free Association Agreement between the United States of America and the Micronesia Treaties and other International Acts (Series 04-625) from 14 May 2003.

Compact of Free Association between the Government of the United States of America and the Government of Palau (48 USC 1931 note; Public Law 99-658) from 1 October 1994.

Fiji Law Reform Commission Act. Available at: $<$ https://laws.gov.fj/Acts/DisplayAct/2295\#> Assess on: 16.08 .2019 .

FRY Greg, TARTE Sandra, The New Pacific Diplomacy, Canberra: Anu Press, 2015. p. 468.

HAFEZ Zakir, The Dimensions of Regional Trade Integration in Southeast Asia, Ardsley: Transnational Publishers, 2004. p. 5.

HERDA Phyllis, REILLY Michael, HILLIARD David, Vision and Reality in Pacific Religion: Essays in Honour of Niel Gunson, Canberra: University of Canterbury, 2005. p. 346.

HUGHES Bob, Report on the South Pacific countries "New Zealand Yearbook of International Law" 2005/2. p. 274.

KLABBERS Jan, An Introduction to International Law, Cambridge: Cambridge University Press, 2011. p. 29.

LANGA'OI Palenitina, The Roots of Instability: Administrative and Political Reform in Tonga, ,Ritsumeikan Journal of Asia Pacific Studies" 25/2009. p.21-35.

LYONS Kate, Australia waters down Pacific Islands plea on climate crisis (15.08.2015), Assess on: <https:// www.theguardian.com/world/2019/aug/15/australiawaters-down-pacific-islands-plea-on-climate-crisis $>$ Available at: 16.08.2019.

MOALA Kalafi, Why Pacific reformers find it difficult (21.07.2015). Available at: <http://pacificpolicy. $\operatorname{org} / 2015 / 07 /$ why-pacific-reformers-find-it-difficult> Assess on: 16.08.2019.

Montevideo Convention on the Rights and Duties of States from 26 December 1933.

NICHOLLS Robert J. and CAZENAVE Anny, SeaLevel Rise and Its Impact on Coastal Zones, "Science" 2010/328(18). p. 1517-1520.

Paris Agreement under the United Nations Framework
Convention on Climate Change from 22 April 2016.

Organisation for Economic Co-operation and Development. Assess on: <https://stats.oecd.org/glossary/ detail.asp?ID=839> Available at: 16.08.2019.

ORŁOWSKA Renata, ŻOLA¿DKIEWICZ Krystyna, Globalizacja i regionalizacja w gospodarcze swiatowej (Globalisation and regionalisation in the world economy), Warsaw: Polskie Wydawnictwo Ekonomiczne, 2012. p. 169-171.

RINARD HINGA Bethany, Ring of Fire: An Encyclopedia of the Pacific Rim's Earthquakes, Tsunamis, and Volcanoes, Santa Barbara: ABC-CLIO, 2015.

SCOTT David, The 21st Century as Whose Century?, "Official Journal of the Political Economy of the WorldSystem Section of the American Sociological Association”, 2007/XIII(2).

SUŁEK Mirosław, SYMONIDES Janusz (ed.), Państwo $w$ teoriach i praktyce stosunków miedsynarodowych (The State in the Theories and Practice of International Relations), Warsaw: Wydawnictwo Uniwersytetu Warszawskiego, 2009. p. 297.

TAUMOEFOLAU Melenaite, Why Tongan has no word for human rights (8.04.2019). Available at: <https://www. newsroom.co.nz/@ideasroom/2019/04/08/521574/ when-are-human-rights-a-right-for-tonga?fbclid= IwAR2itIEjda1KpTwmhZSOt2YHBIzIedH-hMMA8HNxP0HIJtofzfVCdFL61M0\#> Assess on: 16.08.2019.

TERRY Sarah, Where the wave of the future will crest?, "The Christian Science Monitor", 28.09.1982.

UNITED NATIONS HIGH COMMISSIONER FOR REFUGEES, Climate Change and Statelessness: an Overview. Submitted to the UNFCCC 15 June 2009.

VAN TREASE Howard, The Politics of Land in Vanuatu: From Colony to Independence, Suva: Institute of Pacific Studies of the University of the South Pacific, 1987.

VIDAS Davor, The Anthropocene and the international law of the sea, "Philosophical Transactions of the Royal Society”, 2011/369. p. 909-925.

Vienna Convention on the Law of Treaties from 22 May 1969. 
Para publicar na Revista de Direito Internacional, acesse o endereço eletrônico www.rdi.uniceub.br ou www.brazilianjournal.org.

Observe as normas de publicação, para facilitar e agilizar o trabalho de edição. 